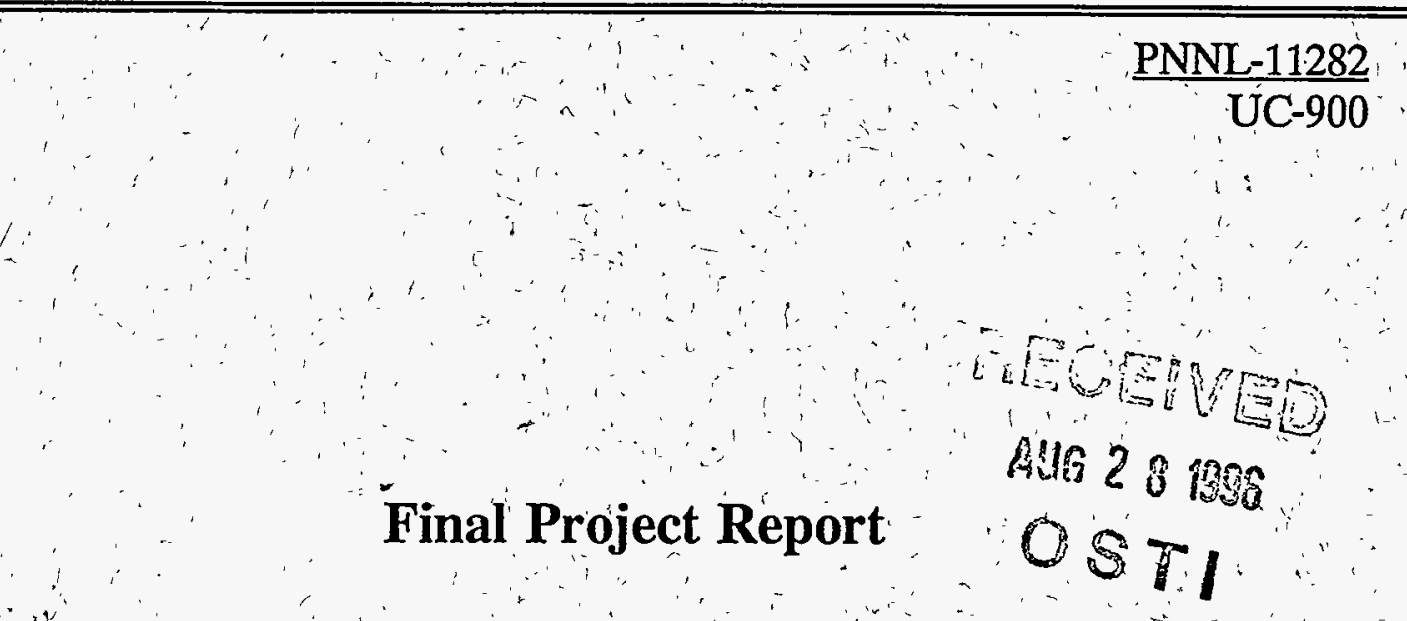

\title{
CRADA with the Belhaven Group and Pacific Northwest National Laboratory (PNL-081): Automated Soil Moisture Measuring Systems
}

K.S. Ramesh

August 1996

Prepared for U.S. Department of Energy: under Contract DE-AC06-76RLO

Pacific Northwest National Laboratory Operated for the U.S. Department of Energy by Battelle Memorial Institute 


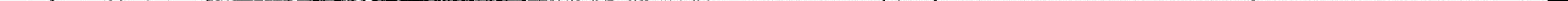




\section{DISCLAIMER}

Portions of this document may be illegible in electronic image products. Images are produced from the best available original document. 
PNL-11282

UC-900

Final Project Report

CRADA with the Belhaven Group and Pacific Northwest National Laboratory (PNL-081): Automated Soil Moisture Measuring Systems

K.S. Ramesh

August 1996

Prepared for U.S. Department of Energy under Contract DE-AC06-76RLO

Pacific Northwest National Laboratory

Operated for the U.S. Department of Energy by Battelle Memorial Institute 


\section{Automated Soil Moisture Monitoring System}

\section{Purpose/Objective}

The objectives of this project were as follows:

- develop an improved, full-scale, inexpensive, soil moisture sensor, using innovative porous ceramic materials as the moisture wicking component

- demonstrate the performance of the sensor in the laboratory and in field to determine , its reliability and accuracy

The opportunity for this project arose as a result of an enquiry from Belhaven to whom the soil moisture sensor developed at PNNL by John Cary was licensed. The existing Cary sensor needed research and development effort in order to create the type of soil moisture sensor envisioned by the Belhaven for use in an integrated soil moisture monitoring systems in the field. PNNL was identified as being uniquely qualified to participate in this collaborative project.

\section{Summary of Activities Performed}

Project activities were initiated in May 1995 (Appendix A). Belhaven is developing an automated version of the PNNL Cary sensor to monitor soil moisture in the field that would provide the capability to optimize water usage by providing the necessary information on where water is needed, how much is needed and when it is needed. Overwatering can lead to excessive leaching of soil nutrients, and have adverse effects in groundwater quality.

The Cary sensor measures moisture content based on the amount of light transmitted through a translucent porous material. The original version of the sensor used Nylon filter which wicks moisture from the soil and becomes increasingly translucent when saturated with water. The increase in light transmittance through the filter is observed from the response of an electro-optical switch. Because the Nylon filters have a single pore size, which is indicative of a single moisture range, it was basically an "on-off" instrument that was incapable of measuring the dynamic range of moisture contents in the soil. It was felt that the sensor's response and accuracy could be improved by replacing the nylon filters with a porous ceramic material with a varied (but known) poresize distribution that will have the hydrophilic properties necessary for drawing water from the soil into the ceramic's interior. The saturation of pore spaces in the ceramic with water will provide a light path that will result in a detectable increase in light transmittance.

\section{Belhaven tasks for this CRADA were;}

- develop improved electronic design for the soil moisture sensor figure 1 (Appendix B) 
- evaluate the response to light with layers of nylon material with different pore sizes placed in a layer-cake configuration that would result in a full scale response to soil moisture content

- evaluate the response to light using a ceramic that would have a well-controlled and narrow range of pore sizes in which case sandwich of multiple ceramic disks could be placed in the sensor.

- evaluate the ceramic having a known distribution of pore sizes that covered the range needed for measuring soil moisture content in which case a single disk could be placed in the sensor.

The tasks performed by PNNL were

- Identify porous ceramic materials with required characteristics having well defined porosity and pore size distribution as shown in figure 2 (Appendix C). Pore size is idetermined by the capillary rise equation as given below:

Measurement of $\Delta \mathrm{P}$ (difference in pressure) can be measurement by the following thermodynamic equation: $\Delta \mathrm{P}=2 \sigma / \mathrm{r} \operatorname{Cos} \theta$

$\Delta \mathrm{P}$ is given by $\mathrm{RT} / \mathrm{r} \mathrm{P} / \mathrm{P}_{0}$ (Osmotic pressure)

or using pressure extraction membrane apparatus

or by Mercury $(\mathrm{Hg})$ intrusion porosimeter

PNNL's primary responsibilities were to identify suitable porous ceramic materials having a well defined porosity with a range of pore size distribution as shown figure 2 .

A thorough literature search was made to identify suitable ceramic material that would be hydrophilic. A lists of bibliography is provided (Appendix D). Information regarding properties of porous ceramic materials and their availability was gathered from a variety of sources. Attempts were made to obtain information from key people involved in the area of moisture sensors.

Ceramic materials in the form of spinels $\left(\mathrm{MgAl}_{2} \mathrm{O}_{4}, \mathrm{MgFe}_{2} \mathrm{O}_{4}\right)$ and Alumina were identified as the possible ceramic materials for evaluation in the automated sensor system. The humidity-dependent electrical properties of porous ceramic are mainly influenced by adsorption and by the capillary condensation of water. The electrical conduction of ceramic materials in most environments is related to proton hoping between water molecules chemisorbed or physisorbed on the ceramic surface. The microstructure of the porous compacts, particularly their pore-size distribution is the primary factor affecting the type and the quality of their electrical behavior. Both total open porosity and pore-size distribution have a great influence on the resistance versus relative humidity sensitivity of the ceramic material. 
No clear conclusion was reached as to what should be the total percent porosity. However, from the figure 2 it was decided to evaluate ceramic materials with $20-40$ percent total porosity having following pore size distribution:

Total percent pores

$20-25$

$15-25$

$30-25$

$35-25$ range (micron)

$0.01-0.1$

$0.1-1$

$1-10 \mu \mathrm{m}$

$10-100 \mu \mathrm{m}$

Based on the market search, a suitable ceramic material with total porosity of 20 - 40 percent having the desired pore size distribution was not available. However, Coors Technical Ceramics Co., assured to provide Alumina material with 40 percent apparent porosity and having pore diameter in the range of 2.6 - 3.4 $\mu \mathrm{m}$ (Appendix E). A range of alumina insulation ceramics having porosities of $80 \%, 70 \%, 60 \%$ and $40 \%$ were obtained from Thermal Ceramics Inc. But the pore size distribution range was not in defined range.

No evaluation of the response to light on a simple ceramic disk or by sandwiching multiple nylon disks, which would have a well-controlled and narrow range of pore sizes, was performed by Belhaven.

Discussions with the Coors Technical Ceramics indicated that they are willing to develop a ceramic material having the desired porosity with the pore size distribution range. A developmental project is envisaged to be a two year program with a total budget of $\$ 250 \mathrm{~K}$.

\section{Significant Accomplishments}

The significant accomplishment of this project were:

- identification of the desired porosity and pore size distribution range for an automated moisture sensor system

- identification of Coors Technical Ceramics Co Ltd as a potential source for developing custom made ceramic material having the desired porosity and pore size distribution. The total budget envisaged is on the order of $\$ 250 \mathrm{~K}$.

\section{Significant Problems}

The major problem in executing this CRADA was non availability of off-the-shelf ceramic material having the desired porosity and pore size distribution. Another question never pursued by Belhaven was whether a significant amount of visible or infrared light can pass through a ceramic material having the defined porosity and pore size distribution. 


\section{Industry Benefits Realized}

Belhaven now has the knowledge of ceramic materials required for improving the automated moisture sensor systems. Additionally, the company can jointly work with the Coors Technical Ceramics in developing the material.

\section{Recommended Follow-On Work}

Important regional crops such as potatoes, onions, and tree fruits are sensitive to not only soil moisture but also nitrate level in the soil. It is possible this sensor can be modified to estimate both moisture and nitrate in the soil. Such a modification would make the instrument much more useful. This should be pursued. 


\section{APPENDIX A}

Belhaven, PNL Form CRADA (Press Release Ceramic Industry) 


\section{REFRACTORIES}

\section{UNITECR Congress}

\section{By: Charles Marvin} The 4th Unified Int'l Technical (UNITECR) will be held at Kyoto Int'] Conference Hall, Kyoto, Japan, Nov. 19-22, 1995 in conjunction with the 8 th Annual Colloquium of Refractories, Japar.

The plenary session is scheduled for Monday, +Nov, 20, following the opening ceremony. Overviews on Refractories for Steel Making in Japan, the Int'l Market-A Borderless World, Latin American Refractories

Requirements and Refractory Application Challenges of the $21 s t$ Century will be presented. The remainder of the threeday program will include 198 papers on global refractory development presented by representatives of more than 30 countries.

Refractories for Steel Making sessions include:

- Blast fumace, coke oven and Torpedo cars (12 papers)

- Tundish and continuous casting (12 papers);

- Degassing and secondary refining (eight papers);

- EAF, BOF and magnesia-carton (19 papers);

- Steel ladles (18 papers).

General topics include:

- Refractoriés for glass, cement and hydrocarbon industries (12 papers):

- Refractories for nonferrous metal industries (fourpapers);

- Raw materials (13 papers).

- Raw materials -China (eight papers);

- Basic science ( 43 papers)

- Monolithic refractories (17 papers);

- Refractories engineering (13 papers);

- New lests and lesting developments (19 papers).

The Technical Association of Refractories, Japar, host for UNITECR 1995, has provided copies of the program and registration information to the American Ceramic Society and The Refractories Institute. The deadline for registration including hotels and tours, is Sept 30, 1995.

Activites for those accompanying conference attendees include a tea ceremony, fower arranging, shopping, rapids shooting, an excursion to Mt. Hiei and Lake Biwa, tours of Kyoto, and poltery and kimono making.

As Japan's capital for more than thousand years, Kyoto served as its political economic and cultural center. Kyoto remains the spiritual homeland of the Japanese people and the premier location for international culture and tourism. It hosts roughly 40 million tourists each year.

Kyoto suffered little damage in the Jan. 17, 1995 earth-" quake, so conference fadities, hotels and airports are operating as usual. All bullet trains to and from Kyoto were. scheduled to be completely repaired by last month, assuring safe passage of. visitors. The bureau also reports autumn foliage, will be at its peak during the conference.

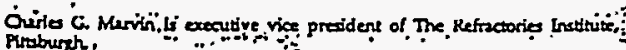

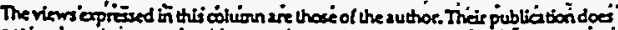
mox inply andotizenent by this on graine

\section{NEWS}

afternoon. State College, Pa. 16801; teletact Vickie Weidler, Conference Planner, 2029 Cato

phone (814) 863-1738, fax (814) $865-3749$.

\section{Chand Kare honored as}

energy pioneer

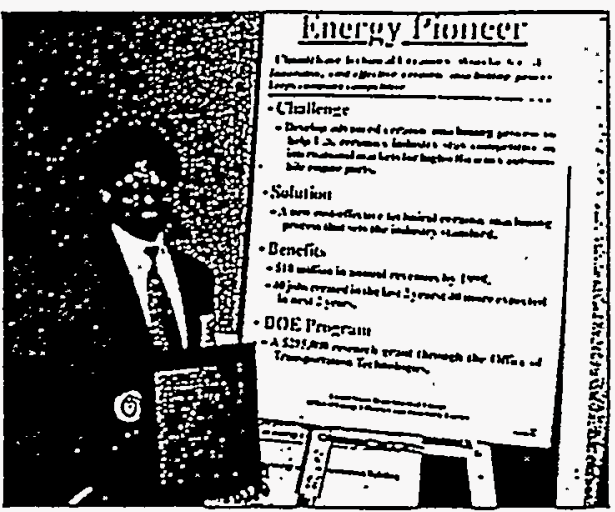

Ron H. Chand, president of Chand Kare Technical Ceramics, receives the Enorgy Pioneer Award from Christine Envin. Assistant Secretary for Energy Efficiency \& Renewable Energy.

DOE has presented Chand Kare Technical Ceramies with its Energy Pioneer Award. The award is pre sented to private sectorcompanies for leadership in partnering with the DOE to commercialize new energy technologies that enhance US. productivity and environmental quality.

With the help of a $\$ 295,000$ DOE grant, the machinin services company based at

\section{Belhaven, PNL form CRADA}

The Belhaven Group, Kennewick, Washington, and Pacific Northwest Laboratory (PNL) haveentered into a CRADA to develop a new system for automatically monitoring soil moisture.

The project, which is ex pected to last a year, will re quire coordinated efforts to produce sensors formeasuring soil moisture as a func tion of light transmitted through porous ceramic through porous ceramic
membranes. The finalobjec-
Worcester, Mass., developed ceramic engine parts that hold the promise of reducing consumers' repair costs and vehicle fuel consumption. Chand Kare developed a standard for determining the grindability of new age techrical ceramics and created close to 50 new jobs in thestates of Massachusetts, Arizona and Maine.

bive is to demonstrate an integrated system using such sensors under field conditions to collect, store and display real-bime data.

Current technology for measuring soil moisture is seportedly unable to deliver low cost. The project team will work to creale a costeffective practical solution to these needs. The team ex pects to find commercial markets for the new technolconsistent precise results at

\section{NEWS}

$\circ g$ in the fields of civil engineering, environmental monitoring and advanced, intelligent agriculture. The hundamental patented technology for this project was. invented.by Dr. John Cary during his employment at PNL In the curmen project, Cary will work with Belhaven's director of tech-

nology, Gene Silvernail, to create prototypes robust enough for long-term field deployment. Dr. KS. Ramesh of PNL will be responsible for the screening and selection of advanced ceramic materials to be incorporated in the final sensor design.

\section{Thermal conductivity call for papers}

Oak Ridge Nat'1 Laboratory, Oak Ridge. Tenn., will host the 23rd Annual Int'l Ther mal Conductivity Conference at Nashville, Tenn. from Oct 29-Nov. 1, 1995.

Papers are being solicited on all aspects of the theory and measurement of ther mal, conductivity and re

lated thermophysical properies and themal phenomena. Abstracts may be sent to Dr. Ralph B. Dinwiddie, OakRidge Nat'I Laboratory, Bldg. 4515, MS 6064, Oak Ridge, Tenn. 37831; telephone (615) 574-7599, fax (615) $574-4913$

\section{Guardian gears up for new plant}

Guardian Industries Corp. Northville, Mich., began construction on its 15th worldwide glass manufacturing plant at DeWitt, Iowa. The $\$ 10$ million facility will manufacture float glass as well as tempered glass, with the possibility of other fabricated glass products being

\section{added in the future.}

Glass produced at the new plant will be utilized by customers in the manufacture of windows, doors, tabletops, mirrors skylights and curtain walls for commercial buildings. The plant is expected to create 250-300 jobs.

\section{American Superconductor to develop prototype power converter}

American Superconductor Corp., Westborough, Mass. announced plans to demonstrate a 75-kw prototype power converter in early 1996 as a step towand developing a commercial version for the market in 1997. The company's CryoPower devices integrate hightemperature superconducting inductor coils with cyocooled power semiconductors and are said to produce more efficient, compact and cost-effective pact and cost-effe
power converters.

power converters.
Benefits of these devices are expected to be realized in situations where large amounts of power $(>100 \mathrm{kw})$ need to be controlled and equipment size and weight are major concerns. Applications may include adjustable-speed drives for large industrial motors; static VAR compersators used by utilities to control power rent rectiliers for metalmelting and electrolysis plants; and transportation and military applications where size and weight are a primary concern. flow and quality; high-cur- 


\section{APPENDIX B}

\section{Typical Sensor Configuration}




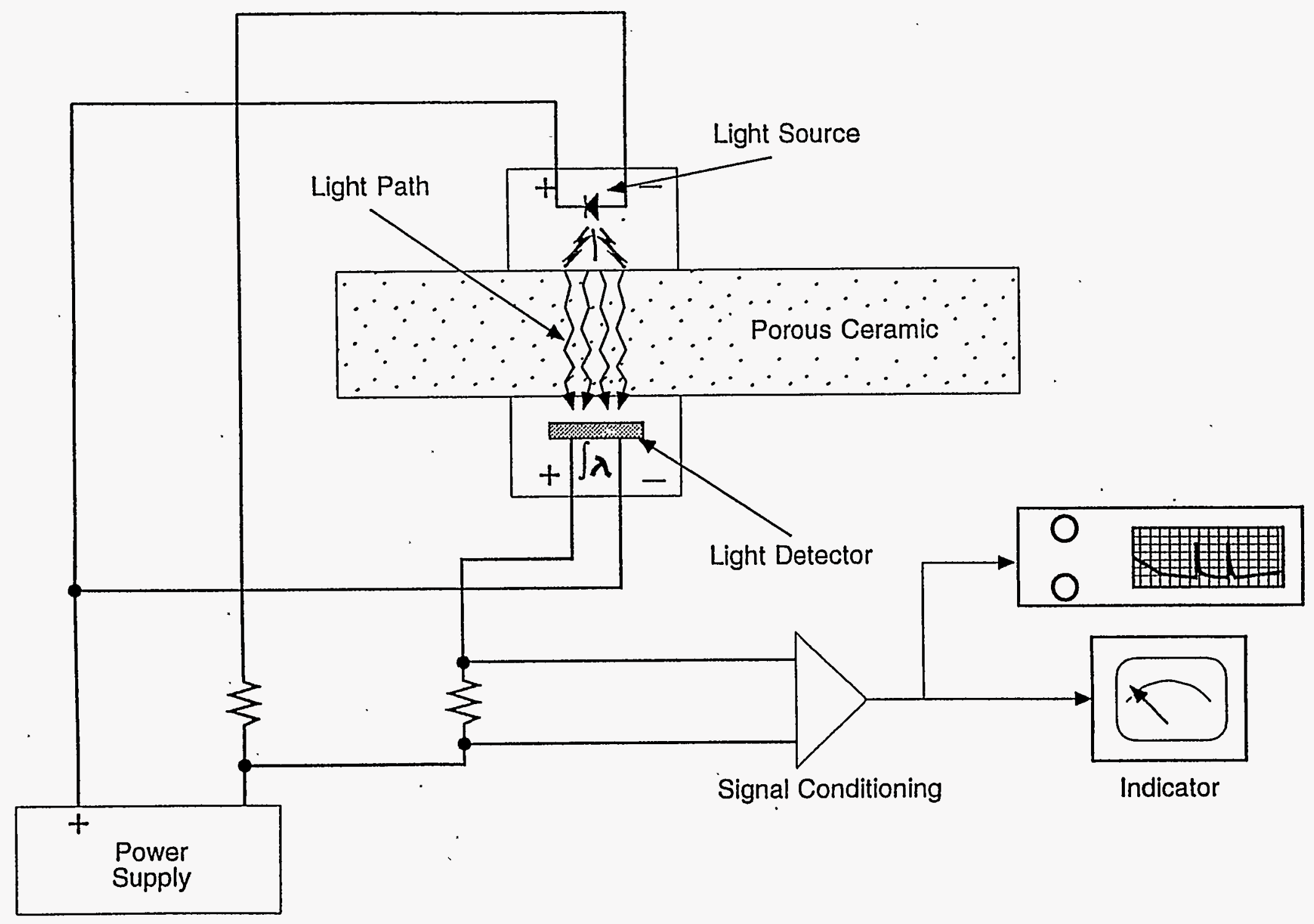

Typical Sensor Configuration 


\section{APPENDIX C}

The Relation Between Pore Diameter (Microns) and Volume

Fraction of Pore Space in Ceramic Material 


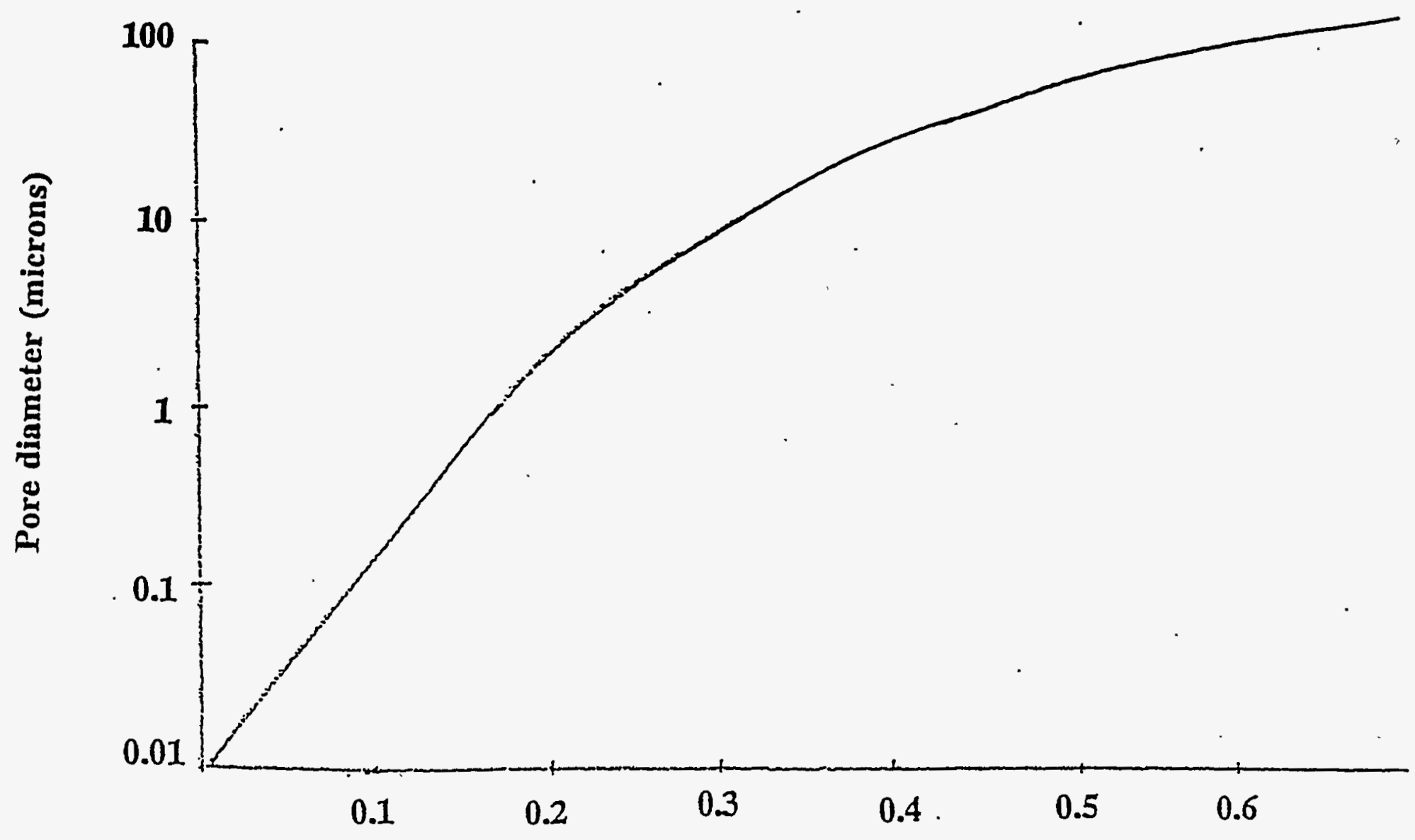

Volume fraction of pore space

Fig. 1 Shows the relations between Pore Diameter (microns) and Volume Fraction of Pore Space in the desired ceramic material 
APPENDIX D

Lists of Bibliography on Humidity/Moisture Sensor Ceramic Materials 


\section{Lists of Bibliography on Humidity/Moisture Sensor}

1. T.Seiyama, N. Yamazoe \& H. Arai, Ceramic Humidity Sensors, Sensors and Actuators (Japanese) 4, 1983 85-96

2. Y.Shimizu; H.Arai and T. Seiyama, Theoretical studies on the impedence humidity characteristics of ceramic humidity sensors, Sensors, 7 (1985) 11-22

3. H.T.Sun, M.T.Wu, P.Li \& X. Yao, Porosity control of humidity-sensitive ceramics and theoretical model of humidity sensitive characteristics, Sensors and Actuators 19, 1989, 61-70

4. G. Gusmano, G. Montesperelli, P. Nunziante and E. Traversa $\mathrm{MgAl}_{2} \mathrm{O}_{4}$ and $\mathrm{MgFe}_{2} \mathrm{O}_{4}$ Spinel Porous Compacts for use in Humidity Sensors, British Ceramic Society Journal and Transactions 92 (1992) No. 3, 104-108.

5. Ceramic Transactions ' Porous Materials' Ed. Kozo Ishizaki, Laurel Sheppard, Shojiro Okada and Toyohiro Hamasaki and Ben Huybrechts, Vol. 31, Published by the American Ceramic Society, Westerville, Ohio, 1992 
APPENDIX E

Typical Properties of Coors Alumina Ceramics 


\section{Properties of Coors Alumina Ceramics}

\% AIUMINA

SEECIFIC GRAVITY

APPARENT POROSITY (MEAN -AVG)

APPARENT POROSITY

ABSORPTION (typical)

MOR (kpsi)

PORE DIAMETER RANGE (MICRON)

BUBBLE PRESSURE PSI

RATE OF FLOW ml H2 o/sec/in2

at 20 psi HEADS

PERMEABIIITY RANGE (MILIIDARCY at 20 p\$i HEAD)
99.1

2.33

40.78

$40.78+1-38$

17.48

8.0

$2.6-3.4$

$12-16$

$0.29 \div 0.31$

$19 \cdot 7-21$ 


\section{Distribution}

No. of

Copies

$\underline{\text { Offsite }}$

Ted Vojnovich

Technical Program Manager

Office of Computational and

Technology Research

Laboratory Technology Research

Division

U.S. Department of Energy

Room G434 (ER-32)

19901 Germantown Road

Germantown, Maryland 20874
No. of

Copies

Onsite

DOE/Richland Operations Office

NL Hieb

K8-50

15 Pacific Northwest National

Laboratory

LA Chick

K2-44

BJ Harrer (2)

K9-21

PM Martin

K3-59

GL McVay

$\mathrm{K} 2-50$

KS Ramesh (3)

K3-59

Information Release Office

(7)

Distri. 1 